\title{
Morphological characterization and molecular identification of Colletotrichum nymphaeae associated with Juglans regia fruit
}

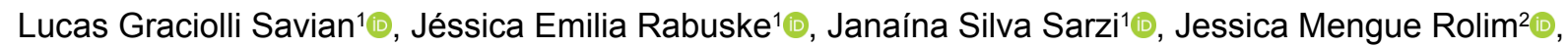

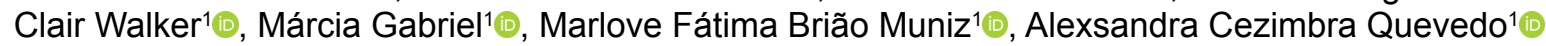

\footnotetext{
1 Universidade Federal de Santa Maria, Santa Maria, RS, Brasil. E-mail: lucassavian@hotmail.com; jessicarabuske@gmail.com; janainasarzi@yahoo.com.br; clairwalker@gmail.com; gabriel.marcia@gmail.com; marlovemuniz@yahoo.com.br; alequevedo1997@gmail.com

${ }^{2}$ Universidade Federal de Pelotas, Pelotas, RS, Brasil. E-mail: eng.jessicarolim@gmail.com
}

ABSTRACT: Juglans regia L., known as Persian walnut, is native to central Asia, where plantations are spread over several countries. The species has a certain importance to humanity, e.g. high quality of the wood. However, the main purpose of cultivation is to obtain edible nuts. In Brazil, the fungus Colletotrichum nymphaeae has significantly damaged the fruit and consequently affected the nut production. Thus, the objective of this study was to verify the pathogenicity and identify, morphologically and molecularly, isolates of Colletotrichum spp. collected from fruit with anthracnose symptoms. The pathogenicity was evaluated in detached fruit and, concerning the morphological characterization, the fungal colonies were grown in Mathur culture medium. The actin region of DNA was used for molecular identification. The isolates of Colletotrichum spp. caused anthracnose symptoms to $\mathrm{J}$. regia fruit. The morphological characteristics of the isolates were similar to those found in species from the Colletotrichum acutatum complex, including the C. nymphaeae. By sequencing the actin genomic region, we confirm that the causal agent of anthracnose in J. regia fruit was Colletotrichum nymphaeae.

\section{Caracterização morfológica e molecular de Colletotrichum nymphaeae associado a frutos de Juglans regia}

RESUMO: Juglans regia L., conhecida como nogueira-chilena, é nativa da Ásia Central, cujos plantios estão distribuídos por inúmeros países. A espécie possui características interessantes ao homem, dentre elas a qualidade da madeira, entretanto, a principal finalidade do cultivo é a obtenção das castanhas comestíveis. No Brasil, o fungo Colletotrichum nymphaeae tem ocasionado danos no desenvolvimento dos frutos e tem afetado a produção de J. regia. Dessa forma, os objetivos deste trabalho foram: testar a patogenicidade do fungo $C$. nymphaeae e caracterizar morfológica e molecularmente isolados de Colletotrichum spp. coletados de frutos de J. regia com sintomas de antracnose. A patogenicidade de C. nymphaeae foi avaliada em frutos destacados e para a caracterização morfológica, as colônias fúngicas foram cultivadas em meio de cultura Mathur. A caracterização molecular foi realizada por sequenciamento da região actina do DNA. Os isolados de Colletotrichum sp. foram patogênicos aos frutos de $\mathrm{J}$. regia. As características morfológicas dos isolados foram compatíveis com as apresentadas por espécies pertencentes ao complexo $C$. acutatum, ao qual $C$. nymphaeae pertence. A região genômica actina foi conclusiva na identificação do agente causal da antracnose em frutos de $\mathrm{J}$. regia identificado como $\mathrm{C}$. nymphaeae.

Palavras-chave: actina; antracnose; nogueira-chilena 


\section{Introduction}

Persian or English walnut (Juglans regia L., Juglandaceae) is a large-sized species, deciduous and native to Central Asia (Hemery, 1998). It is economically important for its quality wood and the nut properties, which are the most consumed in a global scale (Martinez et al., 2010). Due to the increasing demand for walnuts in recent years, its cultivations have expanded substantially, including South American countries, where Chile alone possesses more than 37 thousand hectares for cultivating this species (Muñoz Villagrán, 2017). In Brazil, the species is grown mainly on small properties, for subsistence purposes.

The genus Colletotrichum, the causal agent of anthracnose, is known worldwide for compromising the yield of various crops, causing severe losses that can reach up to $100 \%$. According to Damm et al. (2012), this genus has great scientific and economic importance, for its cosmopolitan nature and for causing damage to several plant species. Among the hosts of species from the genus Colletotrichum spp. are the banana (Musa spp.), olive (Olea europea), black pepper (Capsicum annuum) and rubber tree (Hevea brasiliensis) (Nasehi et al., 2016; Hunupolagama et al., 2017; Iliadi et al. 2018; Riera et al. 2019).

In the recent years, the occurrence of the fungus Colletotrichum nymphaeae has been reported to cause anthracnose in J. regia fruit in the municipality of Anta Gorda, RS, Brazil. The disease affected approximately $50 \%$ of the analyzed fruits, and the lesions were characterized by their dark color (approximately 1.0 in diameter), coalescing after a few days and followed by the fruit fall (Savian et al., 2019). In light of the foregoing, this study aimed to test the pathogenicity and to characterize, by using morphological and molecular characters, isolates from Colletotrichum spp. collected from Juglans regia fruit with anthracnose symptoms.

\section{Materials and Methods}

\section{Collection of the material and site of experiments}

Fruit showing anthracnose symptoms were harvested in a Persian walnut orchard (28 $53^{\prime} 35^{\prime \prime} \mathrm{S}$ and $\left.52^{\circ} 02^{\prime} 45^{\prime \prime} \mathrm{W}\right)$, located in the municipality of Anta Gorda, RS, Brazil. The samples were collected in January 2018, packaged, identified and then taken to the Phytopathology Laboratory "Dra Elocy Minussi", in the Department of Phytosanitary Defense, part of the Federal University of Santa Maria, where the experiments were conducted.

\section{Obtaining the isolates}

The fruit were superficially disinfested by staying 1 min in a solution composed by alcohol at $70 \%$ and sodium hypochlorite at $1 \%$, and afterwards double washed under sterile water. Subsequently, these fruit were placed in gerboxtype boxes and incubated in an acclimatized chamber at 25 $\pm 2{ }^{\circ} \mathrm{C}$, under a $12 \mathrm{~h}$ photoperiod, for two days. The fungal material was isolated by removing structures present in the necrotic regions with the aid of a histological needle and transferred to the center of Petri dishes containing potatodextrose-agar culture medium (synthetic BDA Merck KGaA ${ }^{\circledR}$ ) which were kept in a BOD $\left(25 \pm 2{ }^{\circ} \mathrm{C}, 12 \mathrm{~h}\right.$ photoperiod). When the surface of the culture medium was completely colonized by fungal structures, the isolates were purified using the monosporic culture technique, as described by Fernandez (1993). After five days of growing $\left(25 \pm 2{ }^{\circ} \mathrm{C}, 12 \mathrm{~h}\right.$ photoperiod) the monosporic cultures, the isolates were transferred to test tubes containing the BDA culture medium and stored (Alfenas \& Mafia, 2007) in the laboratory fungi collection, for later use.

\section{Pathogenicity test}

Initially, the colonies of Colletotrichum spp. were cultured in Petri dishes containing Mathur culture medium (25 \pm 2 ${ }^{\circ} \mathrm{C}, 12 \mathrm{~h}$ photoperiod). After fitting the dish with the fungal mycelium, $20 \mathrm{~mL}$ of sterile water was added to each one of them, followed by scraping the surface of the culture medium with a Drigalski handle. Subsequently, the suspension was filtered through double gauze and two drops of Tween ${ }^{\circledR}$ were added in order to keep the conidia under suspension. The counting of the conidia concentration was performed in a Neubauer chamber and the suspension adjusted to $1 \times 10^{6}$ conidia $\mathrm{mL}^{-1}$, by using the Equation 1 .

$$
\mathrm{Vf}=\frac{\mathrm{Vi} \times \mathrm{Ci}}{\mathrm{Cf}}
$$

In which: $\mathrm{Vf}=$ final volume of the suspension, $\mathrm{Vi}=$ initial volume of the suspension, $\mathrm{Ci}=$ initial concentration of conidia $\mathrm{mL}$ counted in the Neubauer chamber and $\mathrm{Cf}=$ desired conidia per $\mathrm{mL}$ concentration.

Fruits of J. regia, free of symptoms and disease signs, previously going through asepsis, were immersed in alcohol at $70 \%$ for 30 seconds, then in a solution with sodium hypochlorite at $1 \%$ for another 30 seconds, and finally twice in sterile water for the same aforementioned time. Subsequently, they were transferred to paper towels for drying purposes. Each peduncle was wrapped in a cotton swab moistened with sterile water for preventing dehydration. Afterwards, the fruits were arranged in gerbox-type boxes lined with two sheets of sterile and moistened filter paper.

In each fruit, a $100 \mu \mathrm{L}$ aliquot of conidia suspension was deposited, split into six drops. In the control treatment, the suspension was replaced by sterile distilled water. For each treatment, three replicates were performed, where each repetition consisted of a fruit. The boxes were covered with plastic and incubated at $25 \pm 2{ }^{\circ} \mathrm{C}$, with a photoperiod of $12 \mathrm{~h}$. The final test evaluation of was at seven days after inoculation, where the incidence of the disease was evaluated visually. When symptoms appeared in at least one of the drops on the fruit, the incidence was considered as positive; if there were no symptoms, it was considered as negative.

At the end of the test, the disease incidence was evaluated as to the presence and absence of symptoms on the fruit and its severity was observed at the place where 
the conidia suspension drops were applied, recording the number of lesions and transforming them into a percentage. A scale was used by assigning scores from 1 to 7 , where $1=$ $0 \%$ (no symptoms); $2=16.6 \%$ (one drop with symptom); $3=$ $33.3 \%$ (two drops with symptom); $4=50 \%$ (three drops with symptom); $5=66.6 \%$ (four drops with symptom); $6=83.3 \%$ (five drops with symptom); $7=100 \%$ (six drops with symptom).

\section{Morphological characterization}

As for the morphological characterization, discs of $7 \mathrm{~mm}$ in diameter of the purified isolates were transferred to Petri dishes $(70 \mathrm{~mm})$ containing Mathur culture medium. The isolates were incubated in an acclimatized chamber for eight days $\left(25 \pm 2{ }^{\circ} \mathrm{C}, 12 \mathrm{~h}\right.$ photoperiod), where the colonies were measured daily in diametrically opposite directions by using digital calipers. For each isolate, six replicates were made, each one composed by a Petri dish.

For determining the sporulation, on the eighth day of growth, $20 \mathrm{~mL}$ of water, distilled and sterile, was added to each Petri dish, and then the surface of the culture medium was scraped by using a Drigalski handle. Sequentially, the suspension was filtered through a double layer of gauze and two drops of Tween ${ }^{\circledR}$ were added. The conidia concentration was determined with the aid of the Neubauer chamber, by the formula: $\mathrm{Ci}=$ (mean number of conidia in the compartments) $x\left(1.6 \times 10^{5}\right)$ (Alfenas \& Mafia, 2007).

As for the characterization of the conidia, 30 units were measured by preparing slides with $1 \mathrm{~mL}$ of the suspension. Conidia were also evaluated as for their format, as proposed by Tozze Júnior (2008). They were randomly chosen and evaluated using an OSM eyepiece, attached to the microscope, at 40x. Each observed conidium was given a numerical name according to the most appropriate format: (1) straight, spindleshaped, with tapered ends; (2) straight, oblong, with rounded ends; (3) straight, club-shaped, tapered at one end and round at the other; (4) straight, constricted (Tozze Júnior, 2008).

For each isolate, 30 appressoria were measured, which were also analyzed as for their form, based on the methodology of Silva (2016), with adaptations. Initially, colonies of the fungal isolates were cultured for eight days on Petri dishes containing Mathur culture medium (2 g peptone, $2.8 \mathrm{~g}$ dextrose, $1.73 \mathrm{~g} \mathrm{MgSO}_{4}, 2.72 \mathrm{~g} \mathrm{KH}_{2} \mathrm{PO}_{4}, 20 \mathrm{~g}$ agar for 1 $\mathrm{L}$ water), according to Mathur et al. (1950) $\left(25 \pm 2{ }^{\circ} \mathrm{C}\right.$ and a $12 \mathrm{~h}$ photoperiod). After this time was depleted, $20 \mathrm{~mL}$ of sterile distilled water was added to each Petri dish, and the surface of the colonies was scraped with a Drigalski handle. The suspension was filtered through a double layer of gauze and the concentration adjusted to $1 \times 10^{6}$ conidia $\mathrm{mL}^{-1}$.

After adjusting the suspensions, a $100 \mu \mathrm{L}$ aliquot of each conidial suspension was deposited on glass slides. These were placed within a gerbox, on a double layer of moistened germitest-type paper and kept in a BOD $\left(25 \pm 2{ }^{\circ} \mathrm{C}, 12 \mathrm{~h}\right.$ of photoperiod), for four days. At the end of this period, a dye drop was added to each slide and they were then viewed using a microscope.

In order to evaluate the presence of fruiting bodies, discs of $7 \mathrm{~mm}$ in diameter, from the isolates were transferred to the middle of Petri dishes containing Mathur culture medium, then kept in an incubation chamber $\left(25 \pm 2{ }^{\circ} \mathrm{C}\right.$, photoperiod $12 \mathrm{~h}$ ) for 15 days. The determination of the colony color was by observing and comparing the underside of Petri dishes, assisted by the Munsell color chart (Munsell Color, 2009), at eight days of incubation.

From the morphological characters (conidial width and length, mycelial growth rate and sporulation) a dendrogram was constructed using the UPGMA (Unweighted Pair Group Method with Arithmetic Mean) clustering method using the GENES 5.0 software. After constructing the dendrogram, only one isolate per formed group was used for the molecular identification.

\section{Molecular characterization}

The genomic DNA was extracted (from mycelium fragments) using the CTAB method (Doyle \& Doyle, 1991), then subjected to the Polymerase Chain Reaction (PCR) for amplifying and sequencing the $\beta$-tubulin ( $\beta$ tub) regions - TUB2F/TUB4F and the actin (ACT) - ACT512F/ACT783R primers. The analysis of the sequenced fragments was with the BioEdit software, where the nitrogenous bases sequences were compared to the ones deposited in the GenBank, with those of the highest coverage and similarity values selected and aligned with the ones obtained in this study, by using the ClustalW algorithm. The phylogenetic analysis was conducted with the "Neighbor-joining" method (1000 replicates), employing the MEGA program (version 7). The nucleotide sequences similarity between the isolates was calculated with the Basic Local Alignment Search Tool - BLAST (http:// blast.ncbi.nlm.nih.gov). The base pair sequences obtained were deposited in the GenBank while the lyophilized fungal samples were deposited in the SMDB Herbarium (Herbarium of the Biology Department from the Federal University of Santa Maria) (Table 1).

Table 1. Isolate code, deposit number in the SMDB e access code in GenBank.

\begin{tabular}{ccc}
\hline Isolate & Access SMDB & $\begin{array}{c}\text { GenBank Code } \\
\text { ACT }\end{array}$ \\
\hline AG02 & 18315 & MN103346 \\
AG05 & 18317 & MK953925 \\
\hline
\end{tabular}

\section{Results and Discussion}

\section{Pathogenicity test}

All isolates were pathogenic to the J. regia fruit. The lesions on these fruit appeared four days after starting the test and the sites inoculated with the conidia suspension had black-colored depressed regions (Table 2 and Figure 1). At the end of the test, fruit inoculated with conidia suspension had at least one lesion in the area where the drops with the conidia were deposited ( $100 \%$ of incidence), while the fruit subjected to the inoculation of water drops alone did not show any apparent symptoms.

In a pathogenicity test of the Colletotrichum gloeosporioides on banana fruits (Musa spp.), Riera et al. (2019) reported the 
Table 2. Pathogenicity of Colletotrichum spp. as a function of the incidence of necrotic spots and the pathogen severity in Juglans regia fruit.

\begin{tabular}{ccc}
\hline Isolate & Lesion per fruit & Severity (\%) \\
\hline AG02 & 4 & 66.67 \\
AG03 & 6 & 100 \\
AG05 & 6 & 100 \\
AG06 & 6 & 100 \\
Control & 0 & 0 \\
\hline
\end{tabular}

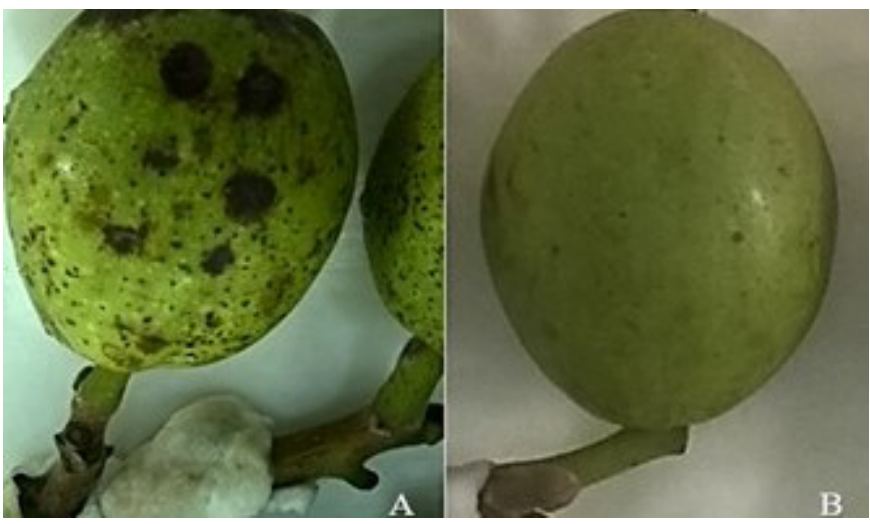

Figure 1. Appearance of Juglans regia fruit at seven days of inoculation with the suspension of Colletotrichum spp. (A); Control without symptoms (B).

appearance of lesions at three days after inoculation while Iliadi et al. (2018) found lesions caused by Colletotrichum acutatum on olive fruits (Olea europea) also after three days of incubation. For $C$. nymphaeae, an agent associated with anthracnose on pepper (Capsicum annuum) in Malaysia, Nasehi et al. (2016) reported appearance of symptoms four days after inoculating the pathogen, which prove the rapid infection by Colletotrichum spp.

Concerning the disease severity, all isolates presented values of $100 \%$, except for the AG02 isolate, with the value of $66.67 \%$. Colletotrichum spp. is a characteristic pathogen that causes spots on leaves and fruit alike, characterized by its high aggressiveness, which causes significant losses in the production (Bedendo, 2018).

\section{Morphological characterization}

The isolates demonstrated little variation between the analyzed characteristics. Regarding the variable final colony diameter, in Mathur culture medium, the values found on the eighth day of incubation ranged from $67.14 \mathrm{~mm}$ for isolate AG06 to $69.56 \mathrm{~mm}$ for isolate AG03 (Table 3). Consequently, the mycelial growth rate had different values between the isolates, from 8.39 to $8.70 \mathrm{~mm} \mathrm{~d}^{-1}$, respectively. In BDA culture medium, the final colony diameter values ranged from 36.53, for isolate AG02, to $46.43 \mathrm{~mm}$ for isolate AG03, which corresponds to the mycelial growth rate of 4.57 and $5.80 \mathrm{~mm}$ $\mathrm{d}^{-1}$ respectively.

Velho et al. (2015), reported that the mycelial growth rate for $C$. nymphaeae isolates is averagely $5.2 \mathrm{~mm} \mathrm{~d}^{-1}$ in the BDA culture medium, values close to those reported by
Table 3. Final Colony Diameter and Mycelial Growth Rate and sporulation of isolates of Colletotrichum spp.

\begin{tabular}{cccccc}
\hline \multirow{2}{*}{ Isolate } & \multicolumn{2}{c}{$\mathrm{FCD}(\mathrm{mm})$} & \multicolumn{2}{c}{ MGR $\left(\mathrm{mm} \mathrm{d}^{-1}\right)$} & \multirow{2}{*}{ Spo. } \\
\cline { 2 - 5 } & Mathur & BDA & Mathur & BDA & $\left(\times 10^{6}\right)^{1}$ \\
\hline AG02 & 67.62 & 36.53 & 8.45 & 4.57 & 3.00 \\
AG03 & 69.56 & 46.43 & 8.70 & 5.80 & 3.01 \\
AG05 & 67.40 & 45.45 & 8.43 & 5.61 & 3.24 \\
AG06 & 67.14 & 43.44 & 8.39 & 5.43 & 1.47 \\
\hline
\end{tabular}

FCD: Colony diameter in $\mathrm{mm}$ at 8 days; MGR: Mycelial Growth Rate in $\mathrm{mm} \mathrm{d}^{-1}$; Spo. Sporulation at 8 days.

Hunupolagama et al. (2017). These authors, when studying the $C$. acutatum complex (to which $C$. nymphaeae belongs) associated with Hevea brasiliensis, found a mycelial growth rate of $5.3 \mathrm{~mm} \mathrm{~d}^{-1}$ for the species $C$. acutatum in BDA medium, with these values being mostly lower than those found in the present study. Some studies demonstrated that Colletotrichum species part of the $C$. acutatum complex, as in the case of $C$. nymphaeae, have a slower growth when in comparison to species from other complexes, such as the gloeosporioides complex (Munir et al., 2016).

However, a factor that influences the final colony diameter is the culture medium. In this study, the variation of the final colony diameter of the isolates in Mathur culture medium or in BDA is attributed to the fact of the first being selective for Colletotrichum spp. For sporulation, isolates AG02, AG03, and AG05 obtained values close to $3.00,3.01$, and $3.24 \times 10^{6}$ conidia $\mathrm{mL}^{-1}$, respectively, while the isolate AG06 obtained a lower result, 1.47 conidia $\mathrm{mL}^{-1}$.

When analyzing the morphological characteristics of $C$. nymphaeae, in SNA culture medium, Yamagishi et al. (2013) found conidia with dimensions of 9.1-14.6 x 2.7-4.5 $\mu \mathrm{m}$, values similar to those found in this present study (Table 4). Velho et al. (2015), also studying this fungus on apple trees in Brazil (Mallus domestica), found conidia of $15.7 \times 5.6 \mu \mathrm{m}$ in BDA culture medium. In a study with $C$. nymphaeae associated with persimmon (Diospyros kaki), Hassan et al. (2019), reported conidia with larger dimensions, from 10.5-18.0 × 4.6-7.8 $\mu \mathrm{m}$, values that are still close to those found in this study.

When characterizing the species responsible for the apple bitter rot in the United States of America, Munir et al. (2016) found a statistical difference between the dimensions of conidia of different species within the $C$. acutatum complex. As for $C$. nymphaeae, the authors observed mean values of $15.41 \times 4.94,15.57 \times 4.91$ and $16.14 \times 4.76 \mu \mathrm{m}$, with a C/L ratio of $3.01,3.17$ and 3.43 , respectively for three isolates.

Table 4. Length, width, length/width ratio and conidia shape of Colletotrichum spp. isolates from Juglans regia.

\begin{tabular}{ccccccccc}
\hline \multirow{2}{*}{ Isolate } & Leng. & Widt. & L/W & \multicolumn{5}{c}{ Shape (\%) } \\
\cline { 5 - 9 } & $(\boldsymbol{\mu m})$ & $(\boldsymbol{\mu m})$ & ratio & $\mathbf{1}$ & $\mathbf{2}$ & $\mathbf{3}$ & $\mathbf{4}$ \\
\hline AG02 & 12.2 & 3.8 & 3.21 & 94 & 3 & 3 & 0 \\
AG03 & 13.1 & 4.5 & 2.91 & 78 & 6 & 10 & 6 \\
AG05 & 13.3 & 4.6 & 2.89 & 63 & 27 & 10 & 0 \\
AG06 & 12.6 & 4.0 & 3.15 & 50 & 33 & 17 & 0 \\
\hline
\end{tabular}

Leng.: Length; Widt.: Width; Conidia shape: 1. straight, spindle-shaped, with tapered ends; 2 . straight, oblong with rounded ends; 3 . straight, club-shaped, tapered at one end and round at the other; 4 . straight, constricted. 
In the present study, the length-width ratio ranged from $2.89 \mu \mathrm{m}$, for isolate AG05, to $3.21 \mu \mathrm{m}$ for isolate AG02, values close to those found by the same authors cited previously (Munir et al. 2016). The predominant conidia shape was type 1 , with straight, spindle-shaped conidia, with tapered ends (Figure 2). Isolate AG02 had the highest percentage of conidia in this format (94\%), while isolates AG03, AG05 and AG06 had 78,63 and $50 \%$ respectively. Another relevant conidia format was the type 2 , being mostly straight, oblong and presenting rounded apices, with isolates AG05 and AG06 having 50 and $33 \%$ of their conidia in this format, respectively. The type 3 format (straight, club-shaped, tapered at one end and round at the other) was found at frequencies of 3,10, 10 and $17 \%$ in isolates AG02, AG03, AG05 and AG06, respectively. Contrary, the type 4 format (straight, constricted) was found only in isolate AG03, corresponding to $6 \%$.

When evaluating the morphology of $C$. nymphaeae, Karimi et al. (2016) reported that the majority of conidia had spindleshaped or cylindrical shape, which is in agreement with the present study. However, according to Damm et al. (2012), many isolates within the $C$. acutatum complex may exhibit spindleshaped conidia, or with a tapered end. According to Menezes (2006), uniformity will also depend on the location where the conidia are produced. The author reports that conidia produced in acervulus are more uniform in physiognomy and dimension than those from conidiogenic hyphae.

Colonies of $C$. nymphaeae in Mathur medium had moderately abundant aerial mycelium of white color, albeit pinkish white on the back of the Petri dish, (Figure 2). Isolates AG02 and AG06 presented, on the eighth day of incubation, a conidia mass of orange color, aggregated around the disk of culture medium used for the test (Figure 3).

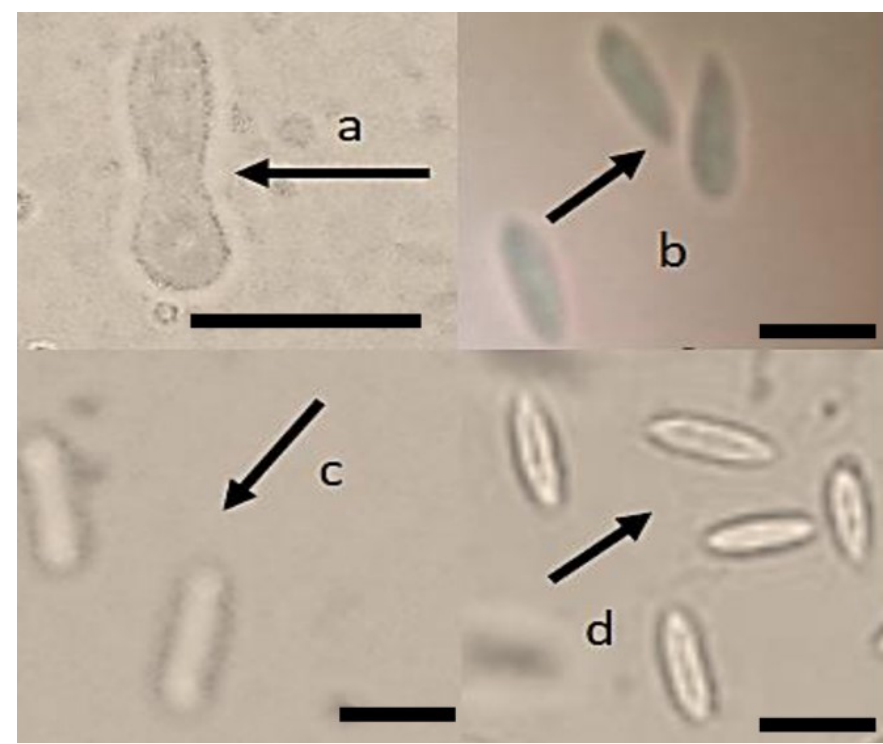

Figure 2. Collidotrichum spp. conidia viewed under a microscope. (a) straight, constricted; (b) straight, club-shaped, tapered at one end and round at the other; (c) straight, oblong, with rounded ends (d) straight, spindle-shaped, with tapered ends. The bar represents $10 \mu \mathrm{m}$.

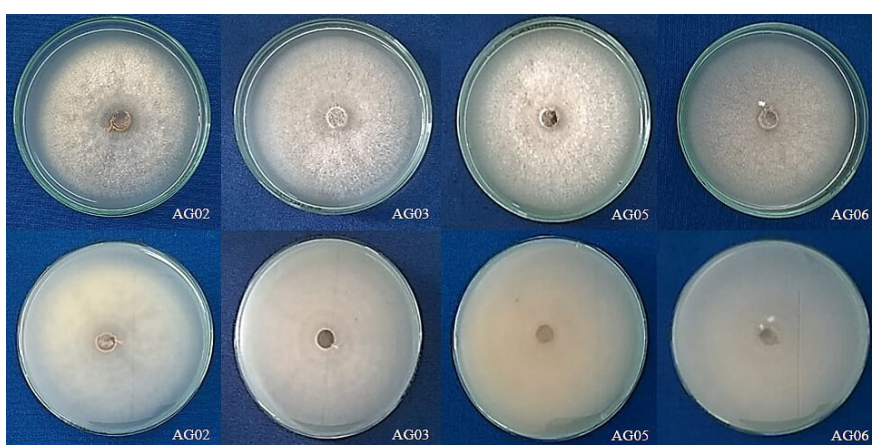

Figure 3. Colonies of Colletotrichum spp. Cultivated in Mathur culture medium, at the eighth day of growth.

The margins from colonies were regular, with uniform appearance over the culture medium, for all isolates. On the other hand, the presence of setae was not observed for any of these. Damm et al. (2012), also found no setae, studying isolates of $C$. nymphaeae in SNA (Spezieller Narstoffarmer Agar) culture medium.

Isolate AG02 did not form an appressorium until the end of the evaluation (Table 5), while the other formed isolates, with dimensions of $11.5 \times 9.5,11.5 \times 9.6$ and $12.1 \times 9.4 \mu \mathrm{m}$ for isolates AG05, AG06 and AG03, respectively. The appressorium is a structure formed due to the expansion of both hyphae and the germ tube, and its formation can be considered an important characteristic for phytopathogenic fungi, since the appressorium firmly adheres to the host tissue, facilitating the penetration and emission of the haustorium (Massola Júnior, 2018).

The morphological characteristics (mycelial growth rate, sporulation, length and width of the conidia) of $C$. nymphaeae isolates were clustered according to their similarity in the dendrogram (Figure 4), by using the UPGMA clustering method

Table 5. Characteristics of Colletotrichum spp. isolated from Juglans regia.

\begin{tabular}{ccccccc}
\hline \multirow{2}{*}{ Isolate } & \multicolumn{5}{c}{ Appressorium } \\
\cline { 2 - 7 } & $\begin{array}{c}\text { Leng. } \\
(\mu \mathrm{m})\end{array}$ & $\begin{array}{l}\text { Widt. } \\
(\mu \mathrm{m})\end{array}$ & \multicolumn{4}{c}{ Shape (\%) } \\
\cline { 3 - 7 } & - & - & & $\mathbf{2}$ & $\mathbf{3}$ \\
\hline AG02 & 12.1 & 9.4 & 86.7 & 10.0 & 3.3 \\
AG03 & 11.5 & 9.5 & 89 & 5.7 & 5.3 \\
AG05 & 11.5 & 9.6 & 80 & 6.7 & 13.3 \\
\hline AG06 & 11.5 &
\end{tabular}

Leng: Length; Widt: Width. Appressoria format: 1. Lobed; 2. Slightly lobed; 3. Rounded.

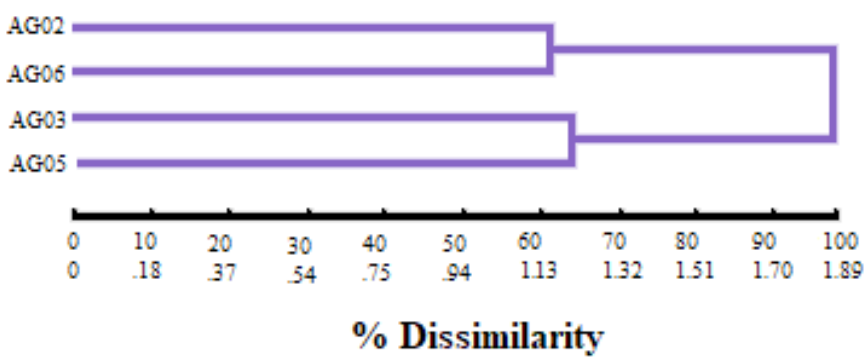

Figure 4. Dendrogram illustrating the dissimilarity percentage among four Colletotrichum spp. isolates. The Dendrogram was obtained by the UPGMA technique, from the analysis of the Euclidean distance matrix with five morphological characters (sporulation, mycelial growth rate, length and width of conidia). 


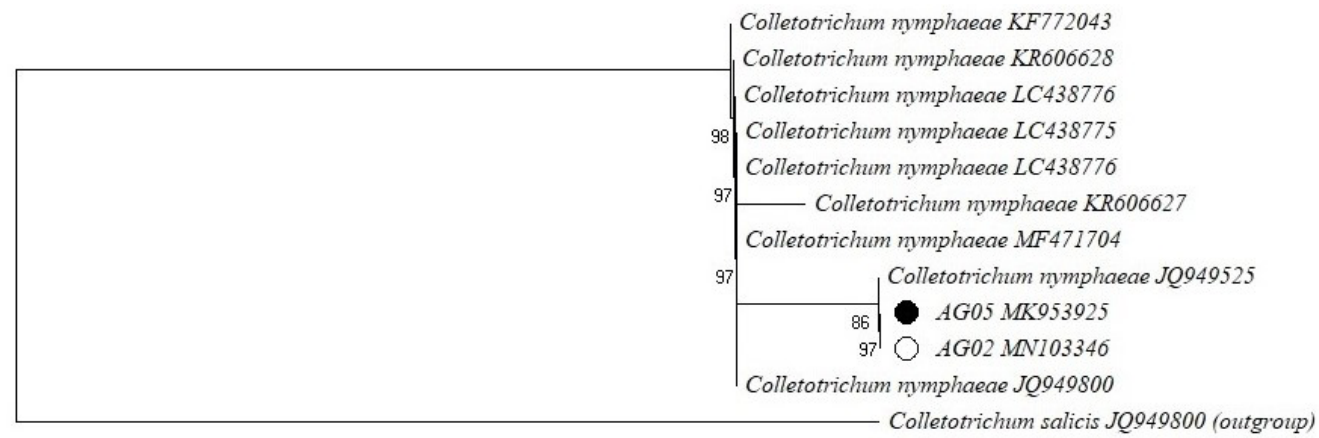

0.01

Figure 5. Phylogenetic dendrogram based on the neighbor-joining method from DNA sequences of the actin region, based on 1000 bootstrap replicates. The number on the branches represents the bootstrap number.

(Unweighted Pair Group Method with Arithmetic Mean). The result of the multivariate analysis allowed visualizing the relative importance with which each trait contributes to the divergence, with the conidia length responsible for $100 \%$ of the divergence, as the other characteristics did not showed statistical difference between the isolates. In the dendrogram (Figure 4) there is the formation of two groups with dissimilarity value greater than $60 \%$ : the first one, with a lower dissimilarity value, was composed by the AG02 and AG06 isolates, while the other one was by the AG03 and AG05 isolates. This result enabled the selection of an isolate from each group ( $A G 02$ and AG05) for DNA extraction and sequencing.

Despite demonstrating typical characteristics from species that are part of the genus Colletotrichum, there is genetic variability and instability of its morphological characteristics, and therefore, using techniques based on these may not be sufficient for differentiating the species accurately, although they are important in the classification process fungi (Massola Júnior, 2018). Thus, complementary and more sensitive methods are needed in the identification of phytopathogens, such as molecular identification (Massola Júnior, 2018).

\section{Molecular characterization}

The $\beta$-tubulin region was not conclusive in identifying the pathogens, therefore it was not described in the present study. Figure 5 illustrates the phylogenetic dendrogram resulting from the alignment of isolates AG02 and AG05 with the actin region sequences of Colletotrichum isolates from the GenBank database. These isolates were identified as $C$. nymphaeae, since they were grouped in a distinct clade with a C. nymphaeae isolate (JQ949525), with the bootstrap value of 86 . Moreover, isolates from this clade demonstrated high genetic similarity with other $C$. nymphaeae isolates deposited in the GenBank, with bootstrap values equal to or greater than 97, indicating that the Colletotrichum isolates in the present study have greater genetic similarity to $C$. nymphaeae than to C. salicis, which was arranged as an outgroup.

The species $C$. nymphaeae is known to cause diseases in several species such as the glomerella leaf spot on apple trees (Mallus domestica). In this disease, the fungus attacks leaves and fruit and the symptoms appear as red-purple spots and defoliation (Moreira et al., 2019). In olive (Olea europea), C. nymphaeae attacks fruits at the beginning of their development, causing a dark brown lesion, also affecting the stalk, causing chlorosis and progressing to necrosis and, consequently, their premature fall (Antelmi et al., 2019).

\section{Conclusions}

The isolates of Colletotrichum spp. were pathogenic to Juglans regia.

During the morphological characterization, the colonies presented, in Mathur culture medium, moderately abundant aerial mycelium, reverse pinkish-white color and regular margin. The formation of clamps, conidia mass, appressoria, and absence of setae were also observed.

The morphological characteristics are similar to those described for the species $C$. nymphaeae, confirmed by the molecular characterization.

\section{Acknowledgements}

The authors would like to thank the Brazilian National Council for Scientific and Technological Development (CNPq) for granting a productivity scholarship to Marlove Fátima Brião Muniz and the Coordination for the Improvement of Higher Education Personnel (Capes) for granting to Lucas Graciolli Savian a master's degree scholarship.

\section{Literature Cited}

Alfenas, A.C.; Mafia, R. G. Métodos em fitopatologia. Editora: UFV, Viçosa, 2007. 382p.

Antelmi, I.; Sion, V.; Nigro, F. First report of Colletotrichum nymphaeae on olive in Italy. Plant Disease, v. 103, n.4, p.765-765, 2019. https://doi.org/10.1094/PDIS-05-18-0847-PDN.

Bedendo, I. P. Podridões de órgãos de reserva. In: Bergamim Filho, A.; Kimati, H.; Amorim L. (Eds.). Manual de Fitopatologia: Princípios e conceitos. 4.ed. São Paulo. Ed. Agronômica Ceres, 2018. v. 1, $573 \mathrm{p}$. 
Damm, U.; Cannon, P. F.; Crous, P. W. The Colletotrichum acutatum species complex. Studies in Mycology, v. 73, p. 37-113, 2012. https://doi.org/10.3114/sim0010.

Doyle, J. J.; Doyle, J. L. Isolation of plant DNA from fresh tissue. Focus, v.12, n.1, p.13-15, 1991.

Fernandez, M. R. Manual para laboratório de fitopatologia. Passo Fundo: Embrapa-CNTP, 1993. 128p. (Embrapa-CNPT. Documentos, 6). http://www.infoteca.cnptia.embrapa.br/ infoteca/handle/doc/815639. 18 Jan. 2020.

Hassan, O.; Lee, D. W.; Chang, T. First report of anthracnose of persimmon caused by Colletotrichum nymphaeae in Korea. Plant Disease, v. 103. n.3, 2019. https://doi.org/10.1094/PDIS-11-18-2114-PDN.

Hemery, G. E. Walnut (Juglans regia) seed collectin gex peditionto Kyrgyzstan in Central Asia. Quarterly Journal of Forestry, v. 92, n. 2, p. 153-157, 1998. http://www.futuretrees.org/files/ uploads/1998-Hemery.pdf. 29 Out. 2019.

Hunupolagama, D. M.; Chandrasekharan, N. V.; Wijesundera, W. S. S.; Kathriarachchi, H. S.; Fernando, T. H. P. S.; Wijesundera, R. L. C. Unveiling members of Colletotrichum acutatum species complex causing Colletotrichum leaf disease of Hevea brasiliensis in Sri Lanka. Current Microbiology, v. 74, p. 747-756, 2017. https://doi. org/10.1007/s00284-017-1238-6.

Iliadi, M.K.; Tjamos, E. C.; Antoniou P.P.; Tsitsigiannis, D.I. First Report of Colletotrichum acutatum causing anthracnose on Olives in Greece. Plant Disease, v. 102, n. 4, p. 820, 2018. https://doi. org/10.1094/PDIS-09-17-1451-PDN. 28 Out. 2019.

Karimi, K.; Aharli, A. B.; Arzanlou, M.; Amini, J.; Pertot I.; RotaStabelli, O. Application of the consolidated species conceptto identify the causal agent of strawberry anthracnose in Iran and initial molecular dating of the Colletotrichum acutatum species complex. European Journal of Plant Pathology, v. 147, n. 2, p. 375-387, 2017. https://doi.org/10.1007/s10658-016-1009-4.

Martinez, M.L.; Labuckas, D.O.; Lamarque, A. L.; Maestri, D.M. Walnut (Juglans regia L.): genetic resources, chemistry by-products. Journal of the Science of Food and Agriculture, v. 90, n. 12, p. 1959-1967, 2010. https://doi.org/10.1002/jsfa.4059.

Massola Júnior, N. S. Fungos fitopatogênicos. In: Amorim, L.; Rezende, A.M.; Bergamin Filho, A. (Eds.). Manual de fitopatologia: princípios e conceitos. v.1. 5.ed. Ouro Fino: Agronômica Ceres, 2018. Cap. 8, p.107-140.

Mathur, R.S.; Barnett, H. L.; Lilly, V. G. Sporulation of Colletotrichum lindemuthianum in culture. Phytopathology, v. 40, n. 1, p. 104114, 1950.

Menezes, M. Aspectos biológicos e taxonômicos de espécies do gênero Colletotrichum. Anais da Academia Pernambucana de Ciência Agronômica, v. 3, p. 170-179, 2006. http://www.journals. ufrpe.br/index.php/apca/article/view/107.
Moreira, R.R.; Peres, N.A.; May, De Mio L.L. Colletotrichum acutatum and $C$. gloeosporioides species complexes associated with Apple in Brazil. Plant Disease. v. 103, n.2, p. 268-275, 2019. https://doi. org/10.1094/PDIS-07-18-1187-RE.

Munir, M.; Amsdem B.; Dixon, E.; Vaillancourt. L.; Ward Gauthieret N. A. Characterization of Colletotrichum species causing bitterroot of apple in Kentucky orchards. Plant Disease, v. 100, n. 11, p. 2194-2203, 2016. https://doi.org/10.1094/PDIS-10-15-1144-RE.

Muñoz Villagrán, M. Nueces: Chile la mayor tasa de crecimiento productivo medio anualSantiago: Odepa, 2017. 10p. https:// www.odepa.gob.cl/wp-content/uploads/2017/12/Nueces.pdf. 28 Out. 2019.

Munsell Color. Munsell soil color charts. New Windsor: Macbeth Division of Kollinorgen Instruments Corporation, 2009.

Nasehi, A.; Kadir, J.; Rashid, T. S.; Awla, H. K.; Golkhandan, E.; Mahmodi, F. Occurrence of anthracnose fruit rot caused by Colletotrichum nymphaeae on pepper (Capsicum annuum) in Malaysia. Plant Disease, v. 100, n. 6, p. 1244-1244, 2016. https:// doi.org/10.1094/PDIS-08-15-0876-PDN.

Riera N.; Ramirez-Villacis, D.; Barriga-Medina, N.; Alvarez-Santana, J.; Herrera, K. First Report of Banana anthracnose caused by Colletotrichum gloeosporioides in Ecuador. Plant Disease, .103, n.4, p.763, 2019. https://doi.org//10.1094/PDIS-01-18-0069-PDN.

Savian, L. G.; Muniz, M. F. B.; Poletto, T.; Maculan, L. G.; Rabuske, J. E.; Sarzi, J. S. Blume, E. First report of Colletotrichum nymphaeae causing anthracnose on Juglans regia fruits in southern Brazil. Plant Disease, v.103, n.12, p.3287, 2019. https://doi.org/10.1094/ PDIS-06-19-1199-PDN.

Silva, M. C. A. Caracterização morfológica, atividade enzimática e processo inicial de colonização de Colletotrichum guaranicola patogênico e endofítico. Manaus: Universidade Federal do Amazonas, 2016. 133p. Tese Doutorado. https://tede.ufam.edu. br/handle/tede/5247. 05 Nov. 2019.

Tozze Júnior, H. J. Caracterização e identificação de espécies de Colletotrichum associadas à antracnose do pimentão (Capsicum annuum) no Brasil. Piracicaba: Universidade de São Paulo, 2008. 82p. Tese de Doutorado. https://doi.org/10.11606/D.11.2008. tde-20032008-151208. 07 Dez. 2019.

Velho, A. C.; Alaniz S.; Casanova, L.; Mondino, P.; Stadnik, M.J. New insights into the characterization of Colletotrichum species associated with apple diseases in southern Brazil and Uruguay. Fungal Biology, v.119, n.4, p. 229-244, 2015. https://doi. org/10.1016/j.funbio.2014.12.009.

Yamagishi, N.; Sato T.; Chuma, I.; Ishiyama Y. Tosa Y.; Anthracnose of black locust caused by Colletotrichum nymphaeae (Passerini) Aa. Journal of General Plant Pathology, v. 82, n. 3, p. 174-176, 2016. https://doi.org/10.1007/s10327-016-0649-8. 